\title{
'A fragment of the explanation': the use and abuse of words
}

Iona Heath General Practitioner, London

\begin{abstract}
This paper explores the normative basis of power in language, story, labels and evidence, and attempts to show how these dimensions of power are used systematically to simplify the reality of exprience, deny ignorance and exclude uncertainty. Through the resulting abuse of words, doctors may often constrain and limit their patients'stories, consigning many of them to stories of failure, and reducing their capacity to celebrate, or even recognise, achievement.

(F Med Ethics: Medical Humanities 2001;27:64-69)
\end{abstract}

Keywords: Language; story; memory; uncertainty; power

This paper starts from the same point as my William Pickles lecture "'Uncertain clarity': contradiction, meaning and hope" but moves in a different direction.

The phrase in the title, "Uncertain clarity", comes from a poem by Zbigniev Herbert, Poland's great postwar poet who died in August 1998 at the age of 73 . His poems were written in stubborn resistance to the political intolerance that surrounded him and this one, in particular, reveals what his translators, John and Bogdana Carpenter, describe as his:

"desire to look closely and intently at the world, at ordinary objects or feelings, stripped of any bias".

The poem is called $\mathrm{Mr}$ Cogito and the Imagination. $\mathrm{Mr}$ Cogito is the protagonist of many of the poems and seems to be Herbert's alter ego. The lines that seem most relevant are:

$\mathrm{Mr}$ Cogito never trusted tricks of the imagination

he adored tautologies

explanations

idem per idem

that a bird is a bird

slavery means slavery

a knife is a knife

death remains death

he loved

the flat horizon

a straight line

the gravity of the earth

he used his imagination

for entirely different purposes he wanted to make it

an instrument of compassion

he wanted to understand to the very end

...

Mr Cogito's imagination

has the motion of a pendulum

it crosses with precision

from suffering to suffering

there is no place in it

for the artificial fires of poetry

he would like to remain faithful to uncertain clarity

This commitment to uncertain clarity is fundamental to general practice: the responsibility to know what we do not know, to be clear about our uncertainty. The great gift of what we do is that every day, if we allow ourselves not only to listen but to hear, we are brought face to face with what we do not know, with the limits of the understanding and power of biomedical science. Herbert requires us not to delude ourselves about the nature of the reality we inhabit and witness. Seamus Heaney describes Herbert's:

"unblindable stare at the facts of pain, the recurrence of injustice and catastrophe". ${ }^{4}$

In another poem, Herbert takes the ancient story of Procrustes and, by naming the victim as a patient, creates (despite his abjuring of such "tricks of the imagination") a metaphor which seems to implicate medicine alongside politics in his condemnation of totalitarianism:

I invented a bed with the measurements of a perfect man

I compared the travellers I caught with this bed

it was hard to avoid-I admit-stretching limbs cutting legs

the patients died but the more there were who perished

the more I was certain my research was right

the goal was noble progress requires victims ${ }^{5}$

When poets create metaphors such as this, doctors should perhaps listen. He seems to argue that a commitment to the uniqueness and aspirations of the individual is an essential defence against the tendency to totalitarianism in science just as much as in politics.

So we have the need to try and see our own limitations with an "unblindable" clarity. 


\section{The allure and tyranny of certainty}

Experts who "know" are wonderfully seductive. Whenever I attend a lecture by someone, usually a hospital specialist, who seems absolutely certain of the correct response to a patient in a particular situation, the temptation to take careful notes is enormous. Yet once I'm back in the consulting room the notes are never as useful as I had hoped they might be. Certainty seems to be born of pretending that things are very much simpler than they really are and in our consulting rooms things never seem simple. Yet there is a terrible certainty about much medical rhetoric and in much of what we say to patients.

Isaiah Berlin would recognise the expert who "knows":

"Happy are those ... who have, by their own methods, arrived at clear unshakeable convictions about what to do and what to be that brook no possible doubt. I can only say that those who rest on such comfortable beds of dogma are victims of forms of self-induced myopia, blinkers that may make for contentment, but not for understanding of what it is to be human."

As would Jose Saramago:

"assuming he has been wise and prudent enough not to believe blindly in what he thinks he knows, because this rather than ignorance is the cause of the greatest blunders".

The pursuit of certainty-the desire for certaintywhat Hans-Georg Gadamer calls "the reduction of truth to certainty" affects the way we use words and language. So I want to explore the use and abuse of words within the interaction between doctor and patient, and examine the normative basis of power in story, language, and knowledge. I hope to show how easy it is for doctors to use these dimensions of power to constrain and limit our patients' stories, consign many of them to stories of failure, and reduce their capacity to celebrate, or even recognise, achievement.

\section{Story}

Patients come to doctors to tell their stories; to give an account of when they first became aware of things being not quite right with their body or mind, of how it all seemed to begin, and how it developed to the point when they felt they must seek the attention of their doctor. But how much of these stories do we hear? The evidence suggests that the patient's whole story is seldom heard. On average, the doctor interrupts after only 18 seconds of the patient's narrative. ${ }^{10}$ Yet, if the patient is allowed to proceed, the full story lasts, on average, only 28.6 seconds, ${ }^{11}$ which seems not much to ask of the listener. ${ }^{12}$ Too often, as doctors, we hear only what we want to hear, and discount what we consider irrelevant.

My childhood general practitioner used to say that illness was what the patient has on their way to see the doctor and disease was what they have on the way home.
We actively constrain our patient's stories of illness to fit the stories of disease: the patterns that medical science has defined in an attempt to make sense of the suffering caused by illness, and to find relief or cure.

"Doctors travel back and forth across the bridge, taking the patient's story of illness to be informed by medicine's abstract knowledge and then to be interpreted and returned to the patient as a presumptive diagnosis retold in the form of a case history." 13

Too often the patient's story is distorted and coerced to fit the patterns of science. The common illness symptoms including headache, tiredness, abdominal pain and many others, can all be caused as much by stress and unhappiness, as by more or less serious disease. Scientific medicine offers much benefit but also carries great dangers, as the frightening prevalence of iatrogenic disease testifies.

"The impersonal constructs of biomedical and social science are far removed from the inner life of fear, love and hope, an inner life which is, moreover, constantly in flux and, often, ambiguous." ${ }^{14}$

If illness caused by unhappiness, anger, loneliness or grief is misinterpreted as being due to disease, the patient will be exposed to the dangers of scientific medicine without the possibility of benefit. Society may also incur the very considerable costs of high tech medicine. ${ }^{15}$ The symptoms and suffering caused by unhappiness are no less real because they do not fit the disease template of scientific medicine. Doctors need always to remember that what the patient feels is the reality of medicine on which doctors must base their practice. The taxonomy of diseases represents the nearest science has got to nature, but it remains a theoretical construct. Only by continuing to listen attentively to our patient's stories of illness will we increase the accuracy and the usefulness of medicine's stories of disease.

"it is important to note the difference between interrogation and dialogue. Questions which admit of only 'yes' or 'no' answers do not allow the respondent to provide a description of his or her experience. ... If the physician is to learn something about the patient's experience he or she must initiate a dialogue with the patient-a dialogue that allows the patient to provide a first person narrative of the illness." ${ }^{\prime 16}$

It is the theory which should be discounted when the patient's symptoms refuse to fit, not the patient's account of the reality of their experience. ${ }^{17}$

What doctors do on a small scale, society does on a much larger scale. Through powerful normative stories of success and achievement, many of our patients are consigned to life stories of failure and unhappiness. But these are rigorously censored stories, surrounded by what Gadamer has described as "the infinity of the unsaid", ${ }^{18}$ which is also represented by the millions of stars left out in the naming of the constellations: 
"Those who first invented and then named the constellations were storytellers. Tracing an imaginary line between a cluster of stars gave them an image and an identity. The stars threaded on that line were like events threaded on a narrative. Imagining the constellations did not of course change the stars, nor did it change the black emptiness that surrounds them. What it changed was the way people read the night sky." ${ }^{19}$

The stories of too many of our patients, perhaps particularly the stories of those who are mentally ill, have been distorted and coerced by social and political pressure, and by abuse and trauma. By our society's standards of success, these become stories of defeat and failure- failure to provide for or hold together a family, failure to hold down a job, failure to achieve educationally or professionally, failure to win the approval of parents or to succeed as parents. But life experience is so rich and complex that every strand of any story simplifies and focuses on one part of an immense continuity (like a photograph? Or like a pattern of stars in the night sky?). Stories are always partial, never complete and never certain. There are always many different stories that could be told. Stories of defeat and failure may also be stories of endurance and survival, often in the face of extraordinary deprivation or exploitation. People tell stories to make sense of their experience and they find meaning by telling the story to others. Life stories are continuously modified by experience and by the reaction of each listener. The reaction of a listening doctor can confirm a story of failure or offer the space and time for the discovery and narration of a different hidden story that is not so stereotyped by the labels inflicted by the conventions of society, medicine and psychiatry. ${ }^{20}$

\section{Language}

Trött på alla som kommer med ord, ord men inget språk

for jag till den snötäckta ön.

Detvilda har inga ord.

Deoskrivna sidorna breder ut sig åt alla håll!

Jagstöter på spåren av rådjursklövar i snön. Språkmen inga ord. ${ }^{21}$

Tired of all who come with words, words but no language

I went to the snow-covered island.

The wild does not have words.

The unwritten pages spread themselves out in all directions!

I come across the marks of roe-deer's hooves in the snow.

Language but no words. ${ }^{22}$

The meaning I take from this wonderful poem is that words alone cannot realise the communication which is the purpose of language. And it seems to me that, if this is the case, we spend too much of our days surrounded by words but no language. How does this happen?

Illness dislocates the sufferer from life and this poem seems to be a little about the same things: about how we need to find the continuity beyond the dislocation, the language beyond the words, the landscape or the life beyond the photograph, the illness and the life history beyond the consultation.

"Each state of mind is irreducible. The mere act of giving it a name, that is of classifying it, implies a falsification of it." ${ }^{23}$

The transformation of a state of mind into a word or words is the beginning of reductionism. Again, with each word, we achieve a degree of certainty at the expense of truth. Mikhail Bakhtin described the way in which words are changed and refracted by each usage- continually subject to both centripetal and centrifugal forces. ${ }^{24}$ As each one of us appropriates words for our own purposes, we add our own particular shade of meaning, producing a centrifugal force which continually develops and fragments language; yet at the same time, all language is social and built on the attempt to achieve shared and centripetal understanding.

Our subjective experience is necessarily lonelyculminating in the ultimate loneliness of death. Language-thoughts and feelings given substance as words-is our defence against that loneliness. Essential to the human struggle to feel less alone, language becomes the bridge between the subjective and the objective, and the bridge between the experience of illness and the symptom related to the doctor (See table 1).

Table 1

\begin{tabular}{ll}
\hline - feelings & $\bullet$ symptom \\
- words & $\bullet$ symptom presentation \\
\hline
\end{tabular}

In each transition we lose some truth and gain some certainty. We need to be aware of the bargain that we have struck to feel less alone and to understand each other, at least to some extent.

All language reflects what we have understood in the past and dictates how we will understand the future:

"The world is different after it has been read by a Shakespeare or an Emily Dickinson or a Samuel Beckett because it has been augmented by their reading of it." 25

In his novel, I Married a Communist, Philip Roth describes the task of the writer like this:

"Your task is not to simplify. Even should you choose to write in the simplest way, ... the task remains to impart the nuance, to elucidate the complication, to imply the contradiction. Not to erase the complication, not to deny the complication, but to see where, within the contradiction, lies the tormented human being. To allow for the chaos, to let it in.... Keeping the particular alive in a simplifying, generalizing world-that's where the battle is joined." ${ }^{26}$

Like writers, and perhaps even more so, doctors must keep the particular alive. Biomedicine is an intensely simplifying and generalising world. We 
make generalisations about people-categorise them-all the time, and as we do so, we simplify, censor and devalue individual experience. And this process can leave individuals feeling unrecognised and the reality of their symptoms unheard.

The longer I work in general practice, the more sceptical I become about the labels and diagnostic categories that we use all the time. Individual patients, with diabetes or asthma, multiple sclerosis or cancer, are so different from one another and seem to experience their diseases so differently that I begin to wonder about the usefulness of the label. And this seems even more true of depression and schizophrenia and personality disorder.

"Maybe labels are useful early in the morning of a work-when the pile to be shifted seems as high as a little mountain -but by noon the labels should have been discarded." (J Berger, personal communication, 2000)

We give people a label to put them in a group so we can learn more about the disease or condition they have in common. To this extent, the generalisation is constructive, but it is also destructive. The general practitioner, while actively using the generalisations of biomedical science, has a constant responsibility to refocus on the individual, the detail of their experience, and the meaning they attach to it.

"The patient gives her opinion of the problem by using a medical term 'palpitations', as if this simple diagnosis would completely decipher her malady."27

It is not surprising that patients should begin to use our labels, but it is one of the ways in which their stories become constrained. In his story, Tlön, Uqbar, Orbis Tertius, ${ }^{23}$ Borges seems to suggest that nouns are about space and verbs about time, with the implication that a single word will never do. Yet in medicine we try to make do with single words, albeit long words, most of the time. But if we accept Borges, we must arrive at the conclusion that medical diagnoses are only about space and not about time, which is interesting and disturbing, particularly as we often link diagnosis to prognosis in a dangerously fatalistic way.

In all these complicated ways, words both free us and trap us.

"When human beings become incorporated in a biomedical, scientific perspective, they lose their identity. ... As a carrier of her own diagnosis, the patient is expected to submit to the concrete actions implied in treatment." 28

We need to work very hard to prevent our patients and ourselves becoming trapped within the words and the language that we use.

"we find that labelling is always a dangerous process ... because it connotes problems as fixed or invariant". ${ }^{29}$

\section{Knowledge}

Our current enthusiasm for what is called "evidence-based medicine" compounds the dangers that I have been trying to describe. Of course it is essential that we seek to base our practice on the current state of scientific knowledge and unless we do this we betray our patients' trust and become quacks and charlatans. But we are bombarded by guidelines, which offer the same false and seductive certainty as the specialist lecturer. These guidelines present medicine as an endeavour that is simple and straightforward. They offer the illusion that each situation can be precisely defined so that the appropriate treatment can be given and the best outcome for the patient and society guaranteed. Working general practitioners know how far this is from the complex reality we inhabit, but I fear that politicians and policy-makers do not.

The complexity lies in the relationship between the population and the individual:

"science can tell us nothing about an individual. Science speaks in terms of probabilities, of means and standard deviations, the behaviour of groups of electrons or proteins or people, not of individual entities. Everything that makes an individual an individual, everything that importantly defines an individual's life, is outside the realm of science. The practice of medicine involves only individuals." ${ }^{30}$

And between the general and the particular:

"It is the task of the power of judgment (and not of teaching or learning) to recognize in a given situation the applicability of a general rule. The task exists wherever knowledge in general is to be applied; the problem is irreducible."

The problem is indeed irreducible and somehow compounded by information technology and the deluge of information it makes available.

"the machine, which forgets nothing, cannot as such remember". 8

Another of Borges's stories, Funes, the Memorious, recounts the short life of Ireneo Funes who, having been thrown from a horse, develops an apparently infinite memory. He is unable to forget a single detail and becomes incapable of thought.

"To think is to forget a difference, to generalize, to abstract." 23

Information must be processed by selection, interpretation and evaluation if it is to become the sort of knowledge that can support the exercise of judgment.

"The concept of information as applied by information theory in no way does justice to the process of selection through which an item of information becomes significant."

The best clinical guidelines can help us locate significant information, but they hold the huge danger of trapping and fossilising knowledge.

I am also convinced

That you only hold a fragment of the explanation. 
It is only because of what you do not understand That you feel the need to declare what you do. There is more to understand: hold fast to that As the way to freedom. ${ }^{31}$

Our awareness of the limitations of our knowledge, our uncertainty, should give us the freedom and the confidence to seek new understanding.

"Knowledge advances through this process of looking for the "unsaid'." 29

I am trying to argue that there are crucially important links between what we hear as doctors and what we don't hear; between what is said and unsaid by both our patients and ourselves; and between the known and the unknown. And that in every case what we have is a fragment of the explanation.

\section{The importance of forgetting}

Gadamer defines health as the ability to forget about one's body and ill health as the inability to forget-a pain, a hurt. ${ }^{8} \mathrm{He}$ describes sleep as rhythmic forgetting and emphasises the poor sleep of ill health. Borges has told us that forgetting is essential to the capacity to think, to find meaning, or to create a story. ${ }^{23}$ We have to ignore some of the stars to see a constellation.

\section{Literacy}

If the full potential of the patient's story is to be realised, the doctor needs to be willing to listen, to hear and to be literate at many different levels. Medical literacy ensures that where the patient has a disease for which medicine offers effective treatment then the pattern of the patient's symptoms will be recognised and appropriate action proposed. Physical literacy ${ }^{32}$ makes use of the doctor's subjective awareness of his or her own body, combined with his or her objective knowledge of the body as a biological specimen. This combination underpins the empathic interpretation of the patient's symptoms that lies at the root of diagnosis. Emotional literacy ${ }^{33}$ allows the doctor to acknowledge and witness the patient's suffering and pain, to stay close, and to help in the struggle to find a way forward. Cultural literacy locates the sufferer within the inclusive story of human experience and endeavour.

"To listen to words, to read them, is consciously or not, to reach out for context, for placement in a meaningful whole." ${ }^{34}$

It generates solidarity and enriches the search for meaning ${ }^{35}$ with examples of the way others have made healing sense of the same sorts of hurt and pain.

The education of doctors gives them knowledge of how the health of individuals and populations could be improved. This confers on doctors a responsibility to retain a vision of how the health of each individual could be improved, and to explore the unknown at the edges of their patients' aspiration. Depending on the particular circum- stances this vision could include social, psychological, physical, economic, nutritional and environmental elements. The vision can be seen as a different story for the patient, which should never be imposed but which can be made available to the patient so that they have a share in the knowledge of how their health could be improved and can make informed choices.

George Steiner asserts that:

"the two validating wonders of mortal existence are love and the future tense". ${ }^{34}$

The future tense allows us all to believe that our lives can be different and it gives us the space to dream and to change. The future tense can offer the patient a different story.

Poets have a similar responsibility to provide an alternative vision and no one writes more eloquently of this responsibility than Seamus Heaney:

"[the] redressing effect of poetry comes from its being a glimpsed alternative, a revelation of potential that is denied or constantly threatened by circumstances". ${ }^{25}$

Poets can teach doctors about the importance of the words that we and our patients use. William Carlos Williams was both a poet and a family doctor, and he wrote:

It is difficult

to get the news from poems

yet men die miserably every day

for lack

of what is found there. ${ }^{36}$

I have tried to explain how, as doctors, we tend to use, and respond to, words, language and stories with too much certainty and that this certainty closes down opportunities and choices for our patients. But my intention is also to show that, as general practitioners, our ability to tolerate uncertainty-our capacity for uncertain clarity-is a great gift and a great skill, which helps to bring both our patients and ourselves closer to the timeless goals of human endeavour-truth and freedom.

Iona Heath is a General Practitioner in London.

\section{Acknowledgement}

A version of this paper has previously been published in AllmänMedicin 2001;22:95-100.

\section{References}

1 Heath I. "Uncertain clarity": contradiction, meaning and hope. British fournal of General Practice 1999;49:651-7.

2 Carpenter J, Carpenter B. Introduction to Z Herbert. Report from the besieged city and other poems. Oxford: Oxford University Press, 1987: viii.

3 Herbert Z. Mr Cogito and the imagination. Report from the besieged city and other poems. Oxford: Oxford University Press, 1987: 17 .

4 Heaney S. The KK. The government of the tongue. London: Faber

5 Herbert Z. Damastes (also known as Procrustes) speaks. See reference 3: 44

6 Berlin I. The pursuit of the ideal. The crooked timber of humanity. London: Fontana Press, 1990: 13-14. 
7 Saramago J. The history of the siege of Lisbon. London: Harvill Press, 1989: 17

8 Gadamer H-G. The enigma of health: the art of healing in a scientific age. Stanford: Stanford University Press, 1996.

9 Payne M. Narrative therapy. An introduction for counsellors. London: Sage Publications, 2000.

10 Beckman HB, Frankel RM. The effect of physician behaviour on the collection of data. Annals of Internal Medicine 1984;101 692-6.

11 Svab I, Katic M. Let the patients speak. Family Practitioner 1991;8:182-3.

12 Coulehan JL. Who is a poor historian? fournal of the American Medical Association 1984;252:221.

13 Jones AH. Literature and medicine: narrative ethics. Lancet Jones AH. Literat

14 Hunt SM. The researcher's tale: a story of virtue lost and regained. In: Joyce CRB, McGee HM, O'Boyle CA, eds. Individual quality of life: approaches to conceptualisation and assessment. Amsterdam. Harwood Academic Publishers, 1999. 15 Barsky AJ, Borus JF. Somatization and medicalization in the era of managed care. Fournal of the American Medical Association 1995;274:1931-4.

16 Toombs SK. The meaning of illness. Dordrecht: Kluwer Academic Publishers, 1993.

17 Rudebeck CE. Humanism in medicine. Benevolence or realism? Scandinavian fournal of Primary Health Care 1992;10 161-2.

18 This quotation from Gadamer is used in reference 29 below.

19 Berger J. And our faces, my heart, brief as photos. New York: Pantheon Books, 1984: 8.

20 Launer J. Narrative and mental health in primary care. In Greenhalgh T, Hurwitz B, eds. Narrative based medicinedialogue and discourse in clinical practice. London: BMJ Books, 1998.

21 Tranströmer T. Från Mars - 79. Dikter. Stockholm: Månpocket, 1997: 163.
22 Tranströmer T. From March 1979. New collected poems. Newcastle upon Tyne: Bloodaxe Books, 1997: 134-5

23 Borges JL. Fictions. London: Jupiter Books, 1965.

24 Bakhtin MM. The dialogic imagination: four essays. Austin: University of Texas Press, 1981.

25 Heaney S. The redress of poetry. London: Faber and Faber, 1995: 159

26 Roth P. I married a communist. London: Vintage, 1998: 223.

27 Puustinen R. Voices to be heard-the many positions of a physician in Anton Chekhov's short story, "A case history". fournal of Medical Ethics: Medical Humanities 2000;26:37-42.

28 Rudebeck CE. General practice and the dialogue of clinical practice: on symptoms, symptom presentations and bodily empathy. Scandinavian fournal of Primary Health Care 1992; (suppl): $1-87$ at 36.

29 Anderson H, Goolishian HA. Human system as linguistic systems: preliminary and evolving ideas about the implications for clinical theory. Family Process 1988;27:371-93.

30 Goodwin JS. Chaos, and the limits of modern medicine. fournal of the American Medical Association 1997;278:1400.

31 Eliot TS. The cocktail party. London: Faber and Faber, 1939.

32 Rudebeck CE. General practice and the dialogue of clinical practice: on symptoms, symptom presentations and bodily empathy. Scandinavian fournal of Primary Health Care 1992; (suppl): $1-87$

33 Adam S. Presentation at the launch of the Chief Medical Officer's annual report for 1996. Royal College of Physicians, 29th November 1997.

34 Steiner G. Errata: an examined life. London: Phoenix, 1998.

35 Midgeley M. Science as salvation: a modern myth and its meaning. London: Routledge, 1992.

36 Williams WC. Asphodel, that greeny flower. New York: New Directions Publishing Corporation, 1955.

\section{News and notes \\ Grant from Pfizer Foundation allows establishment of Centre for Medical Humanities at UCL}

In July of this year the Medical Humanities Unit at the Royal Free and University College Medical School, University College London, was awarded a three-year educational grant from the Pfizer Foundation. The grant is for the establishment of the Centre for Medical Humanities, which replaces the Medical Humanities Unit. Dr Deborah Kirklin has been appointed Pfizer Lecturer in Medical Humanities and will be supported by an administrator and a secretary. The award will enable the centre to expand its work within UCL as well as nationally and internationally both in education and research. Current work includes the first UK short course in medical humanities, the development of an intercalated BSc in medical humanities and an on-line literature, art and film database (LAFD@UCL). An international conference, jointly convened with New York University Master Scholars Programme, will be held at the Royal Society of Arts in March 2002. Further details of the centre's work can be found on http://www.ucl.ac.uk/primcare-popsci/mhu. 